\title{
Overcoming Gender Gaps in Entrepreneurship Education and Training
}

\author{
Nattavud Pimpa * \\ College of Management, Mahidol University, Bangkok, Thailand
}

\section{OPEN ACCESS}

Edited by:

Betina Silva-Lopes,

University of Aveiro, Portugal

Reviewed by:

Soolakshna Lukea Bhiwajee,

University of Technology, Mauritius,

Mauritius

Juan Sánchez García, Miguel F. Martínez Normal School,

Mexico

${ }^{*}$ Correspondence:

Nattavud Pimpa

nattavud.pim@mahidol.ac.th

Specialty section:

This article was submitted to

Language, Culture and Diversity,

a section of the journal

Frontiers in Education

Received: 13 September 2021

Accepted: 24 November 2021

Published: 21 December 2021

Citation:

Pimpa N (2021) Overcoming Gender Gaps in Entrepreneurship Education

and Training.

Front. Educ. 6:774876.

doi: $10.3389 /$ feduc. 2021.774876
Entrepreneurship education and training are essential for female entrepreneurs who juggle family expectations, personal life, and new ventures at the same time. Indeed, generic entrepreneurship training may fail to promote understanding in gender literacy and its relationship with creating and managing business entities. To help address gender gaps, this article explores gender issues in the training process for female entrepreneurs, the researcher collected primary data from 28 trainers through personal interviews and secondary data from the 43 training evaluation forms from trainees who participated in the national entrepreneurship training programs in Thailand. The researcher identifies three themes that are related to gender gaps and effectiveness in the entrepreneurship training context. They include (1) gender mainstreaming, (2) gender-sensitive training approaches, and (3) the adoption of proper technology and innovation for female entrepreneurs. Secondary data also confirm that female entrepreneurs in this study address the need for professional development that promotes them to engage in gender competencies, technology, and innovation for new ventures. The opportunity for professional development can be limited by family and social commitments. Engaging with experienced female entrepreneurs and business role models can promote understanding in the three areas among female entrepreneurs. This article outlines a novel approach in synergizing gender issues, training, and entrepreneurship skills. It concludes with some explanations of the relative efficacy of entrepreneurship training that reduces gender gaps for female entrepreneurs.

Keywords: gender equality, Thailand, entrepreneurship education, feminist theories, SDG \#4, SDG \#10, SDG \#5

\section{INTRODUCTION}

It is evident that entrepreneurship activities contribute to a sustainable economy and gender gap reduction (Galloway and Brown, 2002). The 2020/2021 Global Entrepreneurship Monitor report confirms that entrepreneurial activities and entrepreneurship education can "promote aspiration in life and career as well as the outlook for future business sustainability for women" worldwide. Unfortunately, new businesses and ventures are more likely to be created by men than women (Global Entrepreneurship Monitor, 2020). This issue can be related to limited access to resources to establish new ventures among women. Indeed, it is important for all governments to reduce gender gaps among men and women when it comes to the promotion of business and entrepreneurship opportunities. It is reported by the UN Women (2020a) that the promotion of entrepreneurial mindset through education and training can contribute to gender equity in the participation in entrepreneurship activities among women. Indeed, it is more to do with the creation of 
"mindset" - the psychological and behavioral traits (e.g., creative thinking, problem-solving, opportunity-seeking, and risk assessment) typically associated with the entrepreneurial character (Binks et al., 2006; OECD, 2019). This is reflected in the contemporary entrepreneurship training programs that incorporate creative, technical, and soft skills that help female entrepreneurs remain in the equitable business system (i.e., Binks et al., 2006; Gundry et al., 2014).

In most parts of the world, including Southeast Asia, female entrepreneurs face challenges in starting and growing their businesses, because of gender and cultural-based barriers (Bekh, 2014; OECD, 2019). A report on female entrepreneurship in Southeast Asia by Japan International Cooperation Agency (JICA) (2015) refers to certain structural problems that prevail to reduce gender gaps in entrepreneurial activities. They may include expectation and gender-based roles for women, matrimonial and inheritance laws and/or cultural practices, poor access to resources, limited mobility among women, lack of political voice and representation in society, and an unequal share of family and household responsibilities (Jones and Iredale, 2010). When compared with their male counterparts, women entrepreneurs are in a less competitive position to accessing national and international markets, resources and support, and education and training. Most governments therefore promote entrepreneurship education and training as strategies to mitigate and reduce equality (Balestra, 2018).

A study by Wang et al. (2013) confirms that entrepreneurial activities make significant contributions to economic growth and poverty reduction for and among women, not only in developing countries but also in high-income countries. This can be directly related to the fact that entrepreneurial activities can create new jobs for female entrepreneurs, their family, and friends. Besides boosting employment, women entrepreneurship also supports the diversification of business, stimulating innovation and diversification in management, production, and marketing practices, as well as in products and services. Women offer a variety of management, organizational, and business options.

Barriers for women to establish a new business remain in the modern economy. A gender belief system can have an impact on how men and women operate a business or the industry choice of female entrepreneurs. Sociocultural and educational factors toward women, that is, access to entrepreneurship education and training, may dictate that some industries or professions are more appropriate for female entrepreneurs than others. This point is related to the fact that gender segregation can influence women's opportunities for training, education, and career choices. The result of such attitudes is that specific sector can be oversaturated with female-operated ventures, whereas access to other markets is limited to women entrepreneurs, and thus female entrepreneurial activity in those spheres remains modes (Ugrinova, 2016). Thus, certain industries are seen as "appropriate" for female entrepreneurs because of socially constructed roles (i.e., food, art). On the other hand, technology-intensive markets (i.e., manufacturing, construction) remain primarily reserved for male entrepreneurs. Therefore, gender issues remain problematic in the preparation for skill development among female entrepreneurs.

To ensure that training activities and content match the needs and experiences of women entrepreneurs, research is essential to support the design of entrepreneurship training programs, as well as development and curricula (Jones and Iredale, 2010). In order to understand how to promote effective and relevant entrepreneurship education and training for female entrepreneurs and to reduce gender inequality, this article focuses on the following research questions:

1. When it comes to entrepreneurship education and training, which aspects support gender equality for female entrepreneurs?

2. To what extent can female entrepreneurs develop entrepreneurial skills through informal learning and training?

\section{LITERATURE REVIEW}

\section{Gender Issues and the Entrepreneurship Activities}

Gender disparities among men and women in higher education and technical and vocational education and training are not novel. Indeed, it is confirmed that gender stereotypes, as well as socially constructed roles based on gender, can promote gender disparities in education and training (Kollmayer et al., 2020). Gender disparities can subsequently influence the ability to promote women's empowerment through entrepreneurship education and training. This issue has been confirmed by Diogo et al. (2021), who conclude that, in most organizations, the gender balance decreases with the power of the governing body that may be dominated by men. In terms of professional development and training, women entrepreneurs will face additional challenges in participating in the program, undermining their ability to contribute to inclusive and sustainable growth (UN Women, 2020a).

Reports in this area (i.e., Brush and Green, 2016; Acz et al., 2017; UN Women, 2020b) agree that improving gender disparities in education and training will improve condition of living, socioeconomic status, and political participation among women. When it comes to funding for entrepreneurial activities, the UN Women (2020a) suggested that one approach to empower women is to identify ways for women to be trained and educated, to generate and maintain their own income in the long run. Interestingly. Babbit et al. (2015) conclude that when there is no threat of economic or income loss to an individual's social structure, for example, poverty, then family and social ties are stable, and this has also been shown to have a strong influence in a decision to engage in entrepreneurship activities and training among female entrepreneurs.

Previous studies in gender and entrepreneurship in the global context (i.e., UN Women, 2020a; Sabarwal and Terrell, 2009) focus on the inequality among men and women when it comes to business opportunities. Examining cases from Latin America, Sub-Saharan Africa, Eastern Europe, and Asia, Sabarwal and Terrell (2009) found that female entrepreneurs held smaller 
scales of operation, while gender performance gaps diminished when individual and environmental characteristics were taken into consideration.

Within Southeast Asian countries, Klasen et al. (2011) identify conditions of desperate poverty among women in Thailand and Vietnam (for various reasons such as drought, political issues, disease, and sudden death) as causes of social disintegration, which in turn leads to a desire to improve the family's financial situation. When they engage more in entrepreneurial activities (including education and training), it is likely that they can potentially overcome problems related to poverty much quickly. A study by Global Entrepreneurship Monitor (2020) also confirms that engaging in activities such as learning new technology to explore business opportunities, business innovation, and improving social media skills can improve the quality of life among women from countries in Southeast Asia.

The relationship between entrepreneurship activities and various social and educational conditions can also influence women's engagement in learning and training activities. Issues such as ethnic backgrounds, digital literacy, family roles, and business intention can be strongly related to women entrepreneurs and their participation in a new venture (Brush et al., 2018). Knowlton et al. (2015) also reported three factors affecting gender blind spots in entrepreneurship activities. They include (1) entrepreneurial identity, (2) lack of awareness of support and empowerment programs for female entrepreneurs, and (3) gendered occupational norms.

The literature in this area shows that women's "double burden" (work and family obligations) and other social obligations may lead them to experience more isolation than men entrepreneurs when it comes to participating in various entrepreneurial activities. Apart from social obligations, Balestra (2018) refers to the role of socioeconomic gradients, relative deprivation, and racial discrimination that may contribute to gender inequality in participation in entrepreneurship activities and access to education and training for women.

\section{Gender and Entrepreneurship Learning}

Masculinization of the entrepreneurship training program in many countries has been linked to poor participation among women (Alsubaie and Jones, 2017), as well as a poorer program outcome for women in entrepreneurship education and training programs when compared with men (World Bank, 2015). From the gender perspective, feminist praxis can be adopted to explain the relationship between gender and entrepreneurial training (Freire, 1997; Evans, 2016). In this circumstance, we define praxis as "processes by which theory and practice become closely intertwined with one another" (Evans, 2016). Feminist praxis is a deeper knowledge of how the "intellectual and political" become mutually constituted in the pursuit of gender equality, social justice, and change (Evans, 2016). Institutions also play an important role in this matter. As Mackay et al. (2010) and O'Connor (2020) agree that gender relations are cross-cutting, they play out in different levels, forms, and types of social institutions. Education and training involve various support and access to resources for women to participate in entrepreneurship training. Indeed, access to these resources, and the power they create, has a gender bias (Mackay et al., 2010) that can potentially impede women to progress in entrepreneurial activities.

This engaged approach acknowledges the political implications of intellectual activities to conceptualize entrepreneurship training. The efforts to theorize and investigate entrepreneurship training activities are viewed through the lens of gender, with the goal of gender equality, when feminist praxis is integrated into studies in education and training (Evans, 2016). In addition, previous studies in gender and entrepreneurial activities (UN Women, 2020b) agree that when we incorporate gender issues into the training for entrepreneurs, it must not be perceived as the program that portrays individual women as "victims" of their gendered ascriptions, such as being accepted as a woman but rejected in recognition as great entrepreneurs. This kind of mindset in itself can create gender segregation among men and women in the training program.

As such, calls for the integration of gender equality into education and training activities are not uncommon. It reflects an intellectual recognition of the ways in which gender is an organizing principle in entrepreneurship education and training as well as a political perspective that recognizes women's marginalization from theory and research in the field. Indeed, there must be some vigilance to ensure that gender differences are not exaggerated to the point that they emphasize and reproduce a harmful gendered inequality and hierarchy (UN Women, 2020a).

\section{METHODS}

To explore the gender perspectives of stakeholders in the entrepreneurship training program, the researcher adopted a qualitative research approach. It helps the researcher to understand the perspectives and life and work experiences of the trainers and trainees involved in the professional development and training, curriculum design, and implementation of the programs. Furthermore, this approach enables greater understanding of thought (Hennink et al., 2011), offers visions to different gender problems, and helps in developing concepts or descriptions of experiences among stakeholders in the training programs.

\section{Key Informants}

The researcher collected primary data from 28 trainers who have at least 3 years of experience in the curriculum design, teaching, and evaluation for female entrepreneurs in the nonformal education context. Table 1 displays details of each key informant in the study. Seventy-one percent of key informants in this study are female. Thirteen of them directly involved in the curriculum design. All of them are experienced trainers and educators who provide training for entrepreneurs in the new venture, business, and entrepreneurship training courses/areas. They include topics such as developing business plans, marketing, entrepreneurial financing, and logistics, as well as topics designed to enhance entrepreneurial skills from a gender perspective (such as gender equality, cultural barriers, design thinking for female 
entrepreneurs, and balancing household and business tasks). Only one key informant engages in research and development.

\section{Data Collection}

The researcher contacted the department of informal and nonformal education and asked for their support to select experienced teachers/trainers in the entrepreneurship education section. The research framework and questions were codesigned by staff from the department, academic members from the entrepreneurship and innovation department, and experienced entrepreneurs.

The researcher conducted semistructured personal interviews with all participants, in order to gain in-depth experiences and stories. Prior to the interview, the researcher informed all participants of project objectives and sample questions. Our key informants represent a diverse group of teachers and trainers for female entrepreneurs in different regions in Thailand. The researcher also developed a short interview protocol asking key informants to discuss their experiences working with male and female entrepreneurs, barriers in learning and teaching, and ways to promote gender equality in skill development among male and female entrepreneurs. Interviews ranged the length from $30 \mathrm{~min}$ to $1 \mathrm{~h}$. All interviews were conducted in Thai and subsequently translated into English for the analysis and report. Informed consent was obtained from all individual participants involved in the study. Details of the participants are presented in Table 1.

The researcher asked the trainers to describe their experiences on working with female entrepreneurs, what they found most challenging, and what should be promoted in the future. As the researcher also engaged in the training of the trainers, rapport was built through the training program with the trainers who participated in this study. By the end of the data analysis, all participants received a summary of key findings. They were encouraged to provide feedback to the researcher. At the end, 14 of them submitted extra feedback to the researcher.

In order to obtain the holistic views on gender and training for female entrepreneurs, secondary data were also collected from the evaluations and feedback from female entrepreneurs who attended the training projects. There were 43 sets of evaluation forms that the researcher could get access to for this research project. The data were obtained through the support from the department of nonformal education. Female entrepreneurs from whom we used their feedback for the program were informed about the process with agreement for us to use the data. We focus on their feedback regarding how to improve entrepreneurial learning and skills for future female entrepreneurs who will engage in similar training activities. Table 2 provides a detailed summary of the data collected and its roles in the research process.

\section{Data Analysis}

The research protocol evolved to touch upon various dimensions of training and learning among female entrepreneurs. Given that the presentation of the social and economic contexts is of central importance to qualitative research (Hennink et al., 2011), the researcher created broad categories on gender and training aiming to connect, link, and integrate categories from the data. During the data analysis process for primary data, the researcher focused on extracting meaning from the interview transcriptions and the researcher's note. In so doing, this process helps the researcher to capture stories and narratives from the informants.

A codebook was developed to evaluate the attributes of the participants as well as issues from the secondary data from the female entrepreneurs who participated in the training program. When the researcher concluded the key themes from the data, all participants were contacted to participate in the presentation of the findings. Then, the researcher asked for comments regarding the interpretation of the data as well as the way the stories are told by the researcher in this study. Feedback from participants was subsequently implemented in the final report of this study. They are related to the summary of key themes, written language and how to simplify the language, and suggestions for future research.

Secondary data were analyzed using a framework from Johnston (2014). In the first step, the researcher outlined all variables related to gender issues under the recommendation section in the survey. Literature and themes from the first step were adopted to identify similarities and differences between primary and secondary data, and then the researcher created defined patterns of the data from the secondary data for the conclusion.

\section{Ethics}

This research project is research in humans, which includes identifiable human material and identifiable data. Therefore, the project requires ethical approval. Data were collected in accordance with the code of conduct of research. This study was approved by the ethical committee from Mahidol University.

\section{RESULTS}

\section{Theme 1: Gender Mainstreaming}

Gender mainstreaming in the training process was frequently highlighted by all participants in this study. They mentioned (1) the efforts to examine gender mainstreaming, (2) improved processes of training policy formulation, and (3) implementation from a gender perspective. This process focuses on how to address and correct existing and emerging disparities between men and women in the entrepreneurship training programs. The perceived values of entrepreneurship are strongly related to gender. The training program without proper gender understanding and sensitivity can lead to misperception and gender inequality. Most trainers whom we interviewed addressed certain aspects of gender sensitivity that seem to work for them.

"I pay attention to gender differences, not just men or women but all, both in creating syllabus, program and in-class learning activities." (Trainer, 9)

"I specifically select articles and cases that take gendersensitive approach into the courses readings and assigning some group tasks that demand from students to think about gender aspects in the entrepreneurial process." (Trainer, 12)

Gender-sensitive teaching is thus more inclusive while stimulating critical thinking. All participants in this study 
agree that it is important to equip all entrepreneurs in the training program with a basic understanding of gender and its impacts upon and throughout the entrepreneurial process. Some of them also address that certain information on how socially constructed gender norms affect the daily lives of female entrepreneurs should be included in the training program.

"I can see the energy among female trainees when we started talking about how to manage time and resources as a mother, a daughter, and a business owner. Most of them could draw a strong pattern of relationship among those factors by the end of the training course." (Trainer,15)

All participants agree that a gender-sensitive approach to teaching provides equal opportunity to both female and male teaching staff, attracts entrepreneurs of different genders, and is inclusive for LGBTIQ+ entrepreneurs.

"We introduce our program with a discussion on how men and women are expected in family. They were shocked to realize how limited their business opportunities can be because of social factors." (Trainer, 2)

"In my lesson on access to finance, I realize we do not discuss barriers for female entrepreneurs to gain such access. Discussion on this issue and motivating them (trainees) to explore more information to further design strategies to support female entrepreneurs work very well in my program." (Trainer, 3)

Gender equity in this case (entrepreneurial education and training) refers to fairness in the distribution of resources for training and education to support women to establish business and benefits for both male and female entrepreneurs in the training program. There is a pattern of relationship between gender mainstreaming and training for business establishment among entrepreneurs. It is reported that demographic traits, such as gender, religious background, age, level of education, association with ethnic groups, and experience in employment, can influence the decision to embark on business activities among female entrepreneurs.

"It makes a difference when I know backgrounds of the participants when we prepare to discuss how gender can be related to entrepreneurial activities." (Trainer, 15)

"I worked with female entrepreneurs from Southern Thailand before and I have learned to implement the so-called Southern values into my training. In fact, it helps them to feel at ease in the program." (Trainer, 11)

Gender mainstreaming and financial issues for female entrepreneurs were discussed as an important issue to synergize gender mainstreaming into the training program. Issues regarding how finance disaggregates expenditures in terms of women and men, boys and girls were discussed in some programs. In a broad perspective, it is suggested that the trainers will need to explain how much money and resources are spent on women and how much is spent on men, patterns of spending between men and women, and gender-based finance. The purpose is to determine the impact of existing expenditures between female and male entrepreneurs as well as to review gender-related allocations of resources and opportunities.

Balancing equality and equity in financial literacy and gender budget for business for female entrepreneurs sometimes does mean equal funds; at other times, it means more funds must be allocated to the needs of female or male entrepreneurs. Gender budget training relies on understanding on differences between male and female entrepreneurs on how to operate the business successfully.

"Gender mainstreaming in the finance part is important. I always ask all my trainees to define the relationship between finance and spending patterns between men and women. This kind of activity is important for them" (Trainer, 4)

The majority of the trainers who provide training programs in the areas that are perceived as "feminine" skills, such as language, hospitality and tourism, and cooking, refer to the lack of male students, instructors, and learning and teaching materials that may suit the "macho paradigm" at their institution. They all agree that when the young female entrepreneurs in these areas enroll in such courses or programs, the majority chose to drop out because of the nature of these professions in the gender perception of the public.

"My concern is the lack of male participation when or if we brought gender issues as a foundation for training in home economics and finance. I tried different methods of training. You know, demonstration, online but (paused) the boys were not interested in the issue." (Trainer, 9)

The vast majority of the participants (72\%) also confirm that when they include some experienced entrepreneurs or business owners who act as role models for other female entrepreneurs, students in the program seem to be able to actively engage in the program. They all agree that activities such as study visits, online training with business owners, and virtual case study analysis can stimulate female entrepreneurs to engage with other students. They suggested that, in order to engage female entrepreneurs with other participants and trainers, there should also be outreach programs that support both trainers and trainees to engage with business when the training is completed.

The final point related to gender mainstreaming is that all trainers in this study agree that gender issues should not be delivered as an isolated subject or unit in the training program. When the trainers include gender issues in different units, it helps trainees, in particular female entrepreneurs, to learn beyond the notion of gender as a socially constructed phenomenon in the social context. Some trainers also address that trainees who identify themselves as LGBTIQ+ also value the quality of the training program when gender issues are integrated into learning topics such as entrepreneurial finance, technology management for entrepreneurs, and business law.

"Two of our trainees who call themselves LGBT praise our training program because we work with them and their friends on the impact of gender on seeking financial and nonfinancial resources." (Trainer, 5)

"I remember one of my trainees from the previous group came to me and thank me for addressing gender issues and discussing its impacts on business development since she was feeling that point when she came out to the public while running a team of 50 workers in her business." (Trainer, 19)

It is important that the process of assessing and taking into account the implications for women and men of any planned action including contents, concepts, and programs must be included. This aspect will mitigate inadequate understanding 
of the linkages between gender perspectives in entrepreneurship training and skills development.

\section{Theme 2: Gender and Training Approach}

When female entrepreneurs in this study described their experiences in the program, they unanimously praised the trainers' efforts to get them to participate and "feel a feeling of belonging." This point is pivotal among female entrepreneurs who aim to improve their key entrepreneurial skills. They suggested that the right approach to train entrepreneurs is to know them and listen to them. It is suggested that entrepreneurial training program managers and/or trainers should gather key information from female entrepreneurs who may expect different skill sets from their male counterparts. Information such as learning expectations, life, and work experiences, family, and business network, and expected outcomes will help the trainers to design programs that promote correct approaches in gender inclusiveness and training.

"I collected and used information such as trainee's experiences and their formal education background to design my training curriculum and activities every term." (Trainer, 26)

The most common training methods for female entrepreneurs among participants in this study include lectures, business and experiences sharing, case studies, and coaching by experienced female entrepreneurs. Each approach comes with strengths and weaknesses from the training and gender perspectives. For instance, lectures can be helpful for female entrepreneurs who need explanation in areas such as communicating the business plan for financial support, or gender in the supply chain cycle.

"I gave lectures to the class in areas that focus on information and listen back to them at the end of the session. I found it is effective when we work in a big training session where trainees come from diverse backgrounds and may feel reluctant to engage at the early stage." (Trainer, 28)

"I suggest the trainer conduct need analysis and understand our nature. I teach culinary skills for entrepreneurs, and I need new communication methods to teach my students who operate small shops or restaurants." (Trainer,16)

"My background is teaching English as a second language, so I don't need to repeat what I have already known in this training program. I felt I wasted the first day listening to certain communication issues." (Trainer, 9)

It is not unusual for the training of entrepreneurial skills to include situated-learning scenarios in which learners are often involved. Participants in this study feel that this strategy is beneficial to them as it allows them to connect to the training's fundamental information.

"I adopted a situation that helps female entrepreneurs to consider reasons to support effective communication at the growth stage. Situations related to market and how to promote the new venture from their experiences." (Trainer, 11)

When we attempted to identify the relationship among variables such as outcomes from the training program, learning and teaching strategies, and trainee's expectations from the program, we found that 17 participants focus on the training approach that promotes creativity, locus of control, and risk-taking concept. The participants agree that male and female entrepreneurs may need different approaches when they learn or try to create a new venture.

"When I introduce business pitching to the trainees, most female trainees will need to focus upon demonstration, perhaps more than their male counterparts. When I adopted the use of media, it seems to work better for male entrepreneurs." (Trainer, 5)

As all trainers in this project prioritize technical skills, such as communication, business planning, finance, and digital communication, in the training program, they agreed that when they integrate generic learning to various teaching methods such as online/face-to-face lectures with experiential learning, it can help female entrepreneurs to engage naturally in interpersonal relationships. Development of positive thinking, improvement in interpersonal relationships, proper motivation of people, and organizational development are some of the important benefits of transactional analysis, as a technique of training for female entrepreneurs.

We found from the feedback that the cocreation of a community of inquiry among trainers and female entrepreneurs can benefit both trainees and trainers. More importantly, experienced entrepreneurs are likely to engage in the training program if they can bring their experiences and stories to the training activities.

The participants suggested that skills and gender can be improved when the training approach and gender aspects are synchronized into key themes. Words used by female entrepreneurs in this study to identify the community and their sense of belonging include "communal team," "bonding," "rapport," "trust," and "directness." Data from the program evaluation move into the similar pattern that community of inquiry can reinforce the depth learning in gender-related issues among female entrepreneurs in this study. They also referred to "informal learning," "conversation," "demonstration," "experiential discussions" when describing work-focused training for female entrepreneurs.

\section{Theme 3: Gender and Technology}

It is evident that technology plays a pivotal role among female entrepreneurs in this project. At the very basic level, trainers in the program agree that technology, including social media, can help female entrepreneurs network and motivate each other before and after the training program. Apart from that, we also learn that social norms and context are important factors in the degree of technology awareness, access, and acceptance among female entrepreneurs who attended the programs.

From the interviews, we also learn that female entrepreneurs participating in this program raised an issue regarding constraints in digital literacy. In fact, they addressed that they are constrained by the lack of digital resources, lack of financial resources, and fear of online safety when they started to use simple technology such as e-bidding, or e-payment for business. Given that supports for entrepreneurial training are embedded in gendered entrepreneurship-related institutional systems, female entrepreneurs attending this workshop may still feel inadequate to fully adopt the technology.

In fact, the participants confirmed that almost all trainees are familiar with basic online training and technology such as mobile 
phone applications, online platforms, and electronic databases. In many cases, trainers are familiar with the use of different learning methods and incorporating learning technology to help female entrepreneurs prepare themselves prior to participating in the training. We also learn that training in the nonformal context, with certain online as new learning technology, can provide flexibility to women seeking to advance professionally, socially, and academically.

"Prior to the training, all-female entrepreneurs joined our exclusive Facebook page. We started our informal learning from there. I also encourage them to do frequent online training on e-payment for entrepreneurs." (Trainer, 13)

New technology and media, including e-platform, crowdfund portal, and Kahoot, play a pivotal role in the nonformal entrepreneurial training. When the trainers design how to integrate technology to support female entrepreneurs, they need to explore the backgrounds and experiences of the participants. It is unlikely for all participants to have similar backgrounds and experiences in adopting technology into their business. Hence, the foundation course is also designed as a set of learning experiences for all participants.

It was suggested by the trainers that women entrepreneurs must be able to learn, acquire, and adopt new information and communication technology (ICT) skills and technologies, which they may subsequently use in a variety of business activities. Ten key informants in this study proposed that the government should provide technology that supports the creation of new businesses and start-ups among women entrepreneurs. When we asked what competencies that technology can help female entrepreneurs to create and run a business, the participants mentioned marketing and customer relationship, communication technologies, data for decision, and basic finance.

"My students always ask for training that they can use technology for financial transaction and e-payment." (Trainer, 15)

"I think the business platform is the way to go for modern business. We will need to provide skills for our female trainees to create the new Lazada or Shopee." (Trainer, 2)

When the program includes technology that supports women to recognize, understand, and gain access to resources for new business creation, it is confirmed among participants in this study that they can observe confidence among female entrepreneurs to deeply engage with stakeholders such as innovators, technologists, or experienced business owners by the end of the training program.

"I observe changes among female entrepreneurs from day one and I realize they have gained so much confidence in technology and data for business. They know where to seek help from the experts." (Trainer, 15)

Supports from the government are addressed as a key factor to reduce gender gaps in technology and innovation for female entrepreneurs. This may include grants contributions for technology adoption (e.g., training, research, costs and materials, participation at conferences).

"Our department also seeks financial support from the central government to support new training for women such as platform design and design thinking." (Trainer, 12)
We also learned that increasing awareness about the value of ICTs is another step to change ICT adoption behavior. For example, gender-inclusive, user-friendly diagnostics and curricula may motivate women to investigate ICTs that align with their business expectations. Gender-inclusive entrepreneurship training for trainers, clients, and policymakers may help to reflect on gendered assumptions about ICTs.

Similar to the trainer's views, female entrepreneurs in this study suggested that technology training for entrepreneurs can reduce gender gaps between male and female entrepreneurs. Some of them described several types of personal support to help them deal with technical confusions in certain technologies such as simulations, e-discussion, and data analysis.

The keywords they identify as the roles of technology for gender equality among entrepreneurs include "technology accesses," "women and market information," "online discussion for women," "online mentors," and "ICT facilities for women." They refer to supports that focus on adaptive feedback as well as directions on how to adapt such technologies among female entrepreneurs.

It is obvious that the adoption of technology in the training process can promote not only access to opportunities in training but also ongoing professional development for female entrepreneurs who may be limited to fully participate in the training program because of family and social commitments.

\section{CONCLUSION}

This study has important implications for the providers of entrepreneurial education. This study confirms the view that gender plays various roles in the training for entrepreneurs who may or may not see the fact that gender and inequality in entrepreneurial education remain an important issue. Despite their years of experience as business owner, female entrepreneurs may not feel the urge to challenge the business world on roles of female entrepreneurs who need proper skill development schemes.

Although gender issues in the entrepreneurial process can be intrinsically learned through various approaches, it is important for those who design the training program to prioritize genderrelated issues (Orser et al., 2019). Techniques that can positively promote female entrepreneurs to comprehend the relationship among gender issues, entrepreneurship, and business operations and strategies include experiential learning, the case study through female role models, and debate or ongoing discussion among female entrepreneurs. Gender mainstreaming throughout the program is strongly encouraged by the trainers in this study. Bringing female perspectives into the design will promote ongoing engagement among female entrepreneurs.

We also learn that it is important to promote training activities that are self-directed and informal in nature and learning approaches for female entrepreneurs. As reported by Welter and Smallbone (2003) that, because of human capital gaps, women-owned micro and small enterprises in transition economies are more likely to underperform as compared with 
TABLE 1 | Details of participants/key informants.

\begin{tabular}{|c|c|c|c|c|}
\hline Case & Sex & Taught subjects/areas & Years of experience & Key tasks \\
\hline 1 & $\mathrm{~F}$ & Communication, business plan & 6 & Training, curriculum design \\
\hline 2 & $\mathrm{~F}$ & Negotiation English & 6 & Training, policy \\
\hline 3 & M & Home economics, language & 7 & Training \\
\hline 4 & $\mathrm{~F}$ & Negotiation, writing & S & Material development \\
\hline 5 & $\mathrm{~F}$ & Business plan, entrepreneurship & 8 & Curriculum design, technology implementation \\
\hline 6 & $\mathrm{~F}$ & Finance business English & 13 & Training \\
\hline 7 & $\mathrm{~F}$ & Communication, business plan & 8 & Leadership, training \\
\hline 8 & M & English & 16 & Training and curriculum design \\
\hline 9 & M & English & 13 & Training \\
\hline 10 & $\mathrm{~F}$ & Product development & S & Industry engagement, training \\
\hline 11 & M & English, introduction to marketing & 8 & Research and train \\
\hline 12 & $\mathrm{~F}$ & Work integrated learning, business English, communication & 3 & Curriculum design \\
\hline 13 & $\mathrm{~F}$ & Cooking, English & 13 & Material development, design \\
\hline 14 & $\mathrm{~F}$ & Marketing/management & 12 & Training and curriculum design \\
\hline 15 & $\mathrm{~F}$ & IT/entrepreneurship & 5 & Material development \\
\hline 16 & $\mathrm{~F}$ & Communication, writing & S & Material development \\
\hline 17 & M & English & 15 & Training \\
\hline 18 & M & English, basic science & 16 & Curriculum design \\
\hline 19 & $\mathrm{~F}$ & New product development, design & 5 & Curriculum management, research \\
\hline 20 & $\mathrm{~F}$ & English & 17 & Training \\
\hline 21 & $\mathrm{~F}$ & Work integrated learning & 6 & Curriculum design \\
\hline 22 & $\mathrm{~F}$ & English & 13 & Design and training \\
\hline 23 & $\mathrm{~F}$ & Hospitality & 15 & Curriculum design \\
\hline 24 & $\mathrm{~F}$ & Cooking & 9 & Industry engagement, training \\
\hline 25 & M & Finance & 5 & Training and curriculum design \\
\hline 26 & M & English, introduction to management & 12 & Training and curriculum design \\
\hline 27 & $\mathrm{~F}$ & English & 15 & Training and curriculum design \\
\hline 28 & $\mathrm{~F}$ & English & 6 & Training and curriculum design \\
\hline
\end{tabular}

men-owned businesses. This study further discusses Welter and Smallbone's arguments (2003) by identifying the lack of gender inclusion since the early stage of venture creation. It is indeed suggested that gender issues and their relationship with entrepreneurship skills must be addressed among entrepreneurs and those who promote entrepreneurship activities (i.e., financial institutions, national or local innovation agencies, and education and training agencies).

In so doing, trainers must foster a culture of flexibility in the formal and informal contexts; value flexibility, experimentation, and learning are practiced and valued. It is also suggested in this study that gender sensitivity should be a part of training activities. Training approach that engages female and male entrepreneurs to work on gender issues will enhance their understanding of gender issues. Gender-sensitive training can promote success in the informal entrepreneurial training for women entrepreneurs in this study.

Technology is also an important element for female entrepreneurs who may need access to various innovations and channels (i.e., finance, market, suppliers, customers, knowledge). Providing proper gender-based training for women entrepreneurs is essential as no business can be done successfully without proper technology competencies. More importantly, amid the COVID-19 pandemic, various technologies must be integrated into the business from sourcing to customer relations. If the training program aims to close the gender gap in the adoption of technology among trainees, the inclusion of innovation and technology as key to empowering women entrepreneurs must be codeveloped among the program designers, trainers, and trainees.

When compared with previous studies (i.e., Balestra, 2018; Hennessy, 2003), this article confirms the important roles of socioeconomic gradients and gender sensitivity as the contributing factors to gender inequality in participation in entrepreneurship training activities.

Putting the feminist view into the study, this study addresses that power, institutions, and gender relations are interconnected in various dimensions. Gender relations and masculinity and femininity norms are related when it comes to the design of entrepreneurial activities and learning, by naturalizing and institutionalizing specific arrangements, resources, and power for female entrepreneurs.

\section{Theoretical Implications}

In terms of contributions to theory, this study presents the fact in line with those of Marxist-feminist perspectives on work and social institutions (Hennessy 2003). The inclusiveness of women in the entrepreneurship training and other processes has been raised by participants in this study as a fair go for gender equality. As this study identifies various actions taken by the state (trainers who are state workers), it contributes to understanding on power structure by the state that can directly promote and influence gender equality through the mechanism of entrepreneurship training. It is therefore suggested that the structure of gender relations in entrepreneurship training can be improved by the attempt to incorporate gender aspects into various elements of the entrepreneurship training program. 
TABLE 2 | Description of data.

\begin{tabular}{|c|c|c|c|}
\hline Data type & Description & $\begin{array}{l}\text { Research } \\
\text { questions }\end{array}$ & Use in analysis \\
\hline $\begin{array}{l}\text { Primary data (personal } \\
\text { interviews) }\end{array}$ & $\begin{array}{l}28 \text { Semistructured interviews with } \\
\text { trainers }\end{array}$ & 1,2 & $\begin{array}{l}\text { Provide insights into individual's experiences in gender and entrepreneurship } \\
\text { training programs }\end{array}$ \\
\hline $\begin{array}{l}\text { Secondary data } \\
\text { (feedback) }\end{array}$ & $\begin{array}{l}43 \text { Sets of training evaluation forms } \\
\text { by trainees }\end{array}$ & 1 & $\begin{array}{l}\text { Feedback regarding how to improve entrepreneurial learning and skills for future } \\
\text { female entrepreneurs who will engage in similar training activities }\end{array}$ \\
\hline
\end{tabular}

Findings from this article also extend the gender schema theory. It argues that understanding the "gender gap" in entrepreneurship activities, including training, requires a focus on institutional and structural barriers women entrepreneurs face. This article reorients scholarship in the subject of entrepreneurship and gender through praxis or engaged practice, while also providing approaches to improve gender equality in entrepreneurial training. The theory suggests that women may be expected to be close to a certain set of gender information, which they then encode and organize into networks of mental associations. It allows them to make sense of their worlds and themselves such as being more human-centric for female entrepreneurs. This article argues that the gender schema or cognitive structures that represent information about masculinity-femininity in the training can be improved through the mechanism of training approach that engages gender mainstreaming and the implementation of innovation that equalizes men and women during the training scheme.

\section{Practical and Social Implications}

This article offers suggestions that provide practical implications for those in entrepreneurship training and education. Synergizing gender aspects with the inclusive learning design of the entrepreneurship training programs will reduce gender gaps. It is obvious that inclusion of live stories, work experiences, and backgrounds of all trainees for female entrepreneurs can be developed through the training that promotes experiencing, supporting them to reflect upon the new skills among women, and thinking and acting as an entrepreneur, not a woman.

The combined pedagogy of experiential learning through venture start-up, real-life learning with other women, the narration of business and personal experience, simulation, and apprenticeship can promote equitable training for female entrepreneurs in the long run.

\section{REFERENCES}

Acs, Z. J., Stam, E., Audretsch, D. B., and O'Connor, A. (2017). The Lineages of the Entrepreneurial Ecosystem Approach. Small Bus Econ. 49, 1-10. doi:10.1007/ s11187-017-9864-8

Alsubaie, A., and Jones, K. (2017). An Overview of the Current State of Women's Leadership in Higher Education in Saudi Arabia and a Proposal for Future Research Directions. Administrative Sci. 7, 36-13. doi:10.3390/ admsci7040036

Babbitt, L. G., Brown, D., and Mazaheri, N. (2015). Gender, Entrepreneurship, and the Formal-Informal Dilemma: Evidence from Indonesia. World Develop. 72, 163-174. doi:10.1016/j.worlddev.2015.02.019

\section{Limitations}

As this article focuses on the perspectives of female entrepreneurs, secondary data for this article are exclusive data from female entrepreneurs who attended the training programs, as suggested by the department of nonformal education. The lack of male perspectives on the training process and gender issues may contribute to the limited views on gender equality in the training programs.

It is also possible that in this study we collected primary data directly from the trainers, without including primary data from the entrepreneurs, business community, and the department of education that designed the training programs for the entire nation. Future research should expand views on gender barriers in the training programs for entrepreneurs by examining views from various stakeholders.

\section{DATA AVAILABILITY STATEMENT}

The raw data supporting the conclusion of this article will be made available by the authors, without undue reservation.

\section{ETHICS STATEMENT}

The studies involving human participants were reviewed and approved by The Ethics Committee on Human Subjects, Mahidol University. The patients/participants provided their written informed consent to participate in this study.

\section{AUTHOR CONTRIBUTIONS}

The author confirms being the sole contributor of this work and has approved it for publication.

Balestra, C. (2018). Inequalities in Emerging Economies: Informing the Policy Dialogue on Inclusive Growth. OECD Statistics Working Papers, No. 2018/ 13. Paris: OECD Publishing. doi: $10.1787 / 6 \mathrm{c} 0 \mathrm{db} 7 \mathrm{fb}-\mathrm{en}$

Bekh, O. (2014). Training and Support for Women's Entrepreneurship, ETF Working Paper, European Training Foundation. Available at https://www.etf.europa.eu/ sites/default/files/m/A6FAE24F1DE8FA27C12580DC005F733D_Women $\% 20$ entrepreneurship.pdf.

Binks, M., Starkey, K., and Mahon, C. L. (2006). Entrepreneurship Education and the Business School. Techn. Anal. Strateg. Manage. 18, 1-18. doi:10.1080/ 09537320500520411

Brush, C., and Greene, P. (2016). Closing the Gender gap in Entrepreneurship: A New Perspective on Policies and Practices. Paris: Organization of Economic Cooperation and Development, OECD. 
Brush, C., Edelman, L. F., Manolova, T., and Welter, F. (2018). A Gendered Look at Entrepreneurship Ecosystems. Small Bus Econ. 53, 393-408. doi:10.1007/ s11187-018-9992-9

Diogo, S., Carvalho, T., and Breda, Z. (2021). Nomination vs. Election: Do They Influence Women's Access to Institutional Decision-Making Bodies? J. Manag. Gov 25 (3), 879-898. doi:10.1007/s10997-020-09538-6

Evans, E. (2016). Intersectionality as Feminist Praxis in the UK. Women's Stud. Int. Forum 59, 67-75. doi:10.1016/j.wsif.2016.10.004

Freire, P. (1997). “A Response," in Mentoring the mentor: A Critical Dialogue with Paulo Freire. Editors P. Freire, J. W. Fraser, D. Macedo, T. McKinnon, and W. T. Stokes (New York, NY: Peter Lang), 303-329.

Galloway, L., and Brown, W. (2002). Entrepreneurship Education at university: a Driver in the Creation of High Growth Firms? Educ. Train. 44, 398-405. doi:10.1108/00400910210449231

Global Entrepreneurship Monitor (2020). GEM 2020/2021 Global Report. Available at: https://www.gemconsortium.org/report/gem-20202021-globalreport.

Gundry, L. K., Ofstein, L. F., and Kickul, J. R. (2014). Seeing Around Corners: How Creativity Skills in Entrepreneurship Education Influence Innovation in Business. Int. J. Manage. Educ. 12, 529-538. doi:10.1016/ j.ijme.2014.03.002

Hennessy, R. (2003). "Class," in A Concise Companion to Feminist Theory. Editor M. Eagleton (Malden, MA: Blackwell).

Hennink, M., Hutter, I., and Bailey, A. (2011). Qualitative Research Methods. Thousand Oaks, CA: Sage.

Japan International Cooperation Agency (JICA) (2015). Project for Strategic Strengthening of Small and Medium Enterprise (SME) Support System: Final Report. Kingdom of Cambodia, Phnom Phen, Cambodia: Ministry of Industry and Handicraft. Available at: https://openjicareport.jica.go.jp/pdf/ 12245049_01.pdf.

Johnston, M. (2014). Secondary Data Analysis: A Method of Which the Time Has Come. Qual. Quan. Met. Lib. 3 (3), 619-626.

Jones, B., and Iredale, N. (2010). Enterprise Education as Pedagogy. Educ. Train. 52, 7-19. doi:10.1108/00400911011017654

Klasen, S., Lechtenfeld, T., and Povel, F. (2011). What about the Women? Female Headship, Poverty and Vulnerability in Thailand and Vietnam, OECD. Available at: https://www.oecd.org/dev/pgd/46982877.pdf.

Kollmayer, M., Schultes, M.-T., Lüftenegger, M., Finsterwald, M., Spiel, C., and Schober, B. (2020). REFLECT - A Teacher Training Program to Promote Gender Equality in Schools. Front. Educ. 5, 136. doi:10.3389/feduc.2020.00136

Mackay, F., Kenny, M., and Chappell, L. (2010). New Institutionalism through a Gender Lens: Towards a Feminist Institutionalism? Int. Polit. Sci. Rev. 31 (5), 573-588. doi:10.1177/0192512110388788

O'Connor, P. (2020). Why Is it So Difficult to Reduce Gender Inequality in MaleDominated Higher Educational Organizations? A Feminist Institutional Perspective. Int. Sci. Rev. 45 (2), 207-228. doi:10.1080/03080188.2020.1737903

OECD (2019). "Entrepreneurial Learning and Women's Entrepreneurship (Dimension 1) in the Western Balkans and Turkey," in SME Policy Index: Western Balkans and Turkey 2019: Assessing the Implementation of the Small Business Act for Europe (Paris: OECD Publishing). doi:10.1787/34345065-en
Orser, B., Riding, A., and Li, Y. (2019). Technology Adoption and Gender-Inclusive Entrepreneurship Education and Training. IJGE 11, 273-298. doi:10.1108/ IJGE-02-2019-0026

Sabarwal, S., and Terrell, K. (2009). Does Gender Matter for Firm Performance? Evidence from Eastern Europe and Central Asia. IZA Discussion Papers No. 3758. Available at https://repec.iza.org/dp3758.pdf.

Ugrinova, R. (2016). Female Education and Entrepreneurship as Drivers of Economic Development: How the Right to Education Can Enhance Female Entrepreneurship and Contribute to Economic Growth. Master thesis. Tilburg University. Available at: http://arno.uvt.nl/show.cgi? fid $=142482$.

UN Women (2020a). Progress on the Sustainable Development Goals: The Gender Snapshot 2020. Available at: https://www.unwomen.org/sites/default/files/ Headquarters/Attachments/Sections/Library/Publications/2020/Progress-onthe-Sustainable-Development-Goals-The-gender-snapshot-2020-en.pdf.

UN Women (2020b). Fund for Gender Equality Annual Report 2019-2020. Available at: https:/www2.unwomen.org/-/media/headquarters/attachments/ sections/library/publications/2020/fund-for-gender-equality-annual-report2019-2020-en.pdf?la=en\&vs=4858.

Wang, Y. L., Ellinger, A. D., and Jim Wu, Y. C. (2013). Entrepreneurial Opportunity Recognition: an Empirical Study of R\&D Personnel. Manage. Decis. 51, 248-266. doi:10.1108/00251741311301803

Watkins, K. K., Ozkazanc-Pan, B., Clark Muntean, S., and Motoyama, Y. (2015). Support Organizations and Remediating the Gender Gap in Entrepreneurial Ecosystems: A Case Study of St. Louis. SSRN J. doi: $10.2139 /$ ssrn.2685116

Welter, F., and Smallbone, D. (2003). "Entrepreneurship and Enterprise Strategies in Transition Economies: An Institutional Perspective," in Small Firms and Economic Development in Developed and Transition Economies: A Reader. Editors D. Kirby and A. Watson (Burlington, Vermont: Ashgate), 95-114.

World Bank (2015). Female Entrepreneurship: Program Guidelines and Case Studies. Available at: http://siteresources.worldbank.org/EXTGENDER/ Resources/FemaleEntrepreneurshipResourcePoint,041113.pdf.

Conflict of Interest: The authors declare that the research was conducted in the absence of any commercial or financial relationships that could be construed as a potential conflict of interest.

Publisher's Note: All claims expressed in this article are solely those of the authors and do not necessarily represent those of their affiliated organizations, or those of the publisher, the editors, and the reviewers. Any product that may be evaluated in this article, or claim that may be made by its manufacturer, is not guaranteed or endorsed by the publisher.

Copyright (C) 2021 Pimpa. This is an open-access article distributed under the terms of the Creative Commons Attribution License (CC BY). The use, distribution or reproduction in other forums is permitted, provided the original author(s) and the copyright owner(s) are credited and that the original publication in this journal is cited, in accordance with accepted academic practice. No use, distribution or reproduction is permitted which does not comply with these terms. 